\title{
Peanuts, Corn, And Other Cereal Grains Can Be Toxic To Wild Birds ${ }^{1}$
}

\section{Kristen L. Candelora and William M. Giuliano ${ }^{2}$}

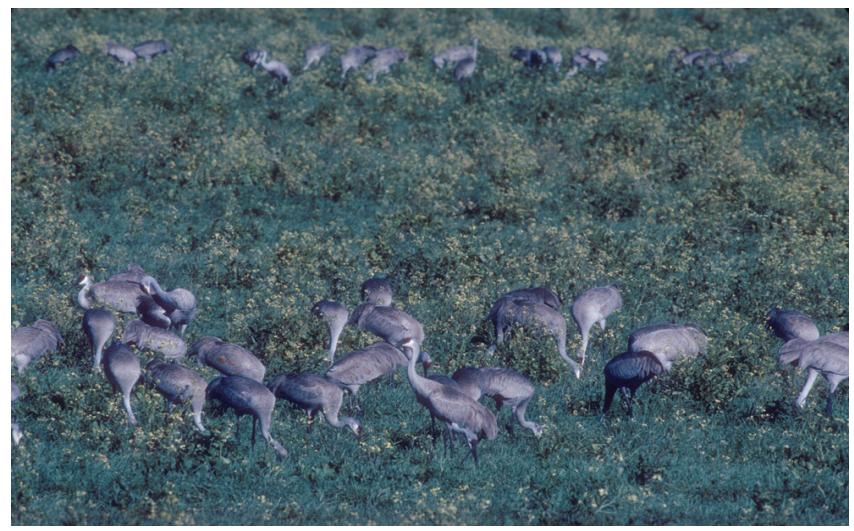

Figure 1. Sandhill cranes foraging in a peanut field. Under certain conditions, unharvested peanuts, corn, and other grains may grow a fungus that when ingested by birds can be fatal. Credits: Photo by FWC/S. Nesbitt.

It is nearly impossible to harvest $100 \%$ of any crop. Often what is left over remains on the ground, available to wild birds as a potential source of food. However under certain circumstances, eating these "leftovers" can pose a serious health risk to wild birds. The reason for this is that peanuts, corn, and other cereal grains may grow a fungus/mold that produces poisons called mycotoxins. These mycotoxins can be deadly to the wild birds that feed on them (Figure 1). The fungi can grow on the unharvested crops left behind, or on harvested crops during storage and transportation. There are many different types of mycotoxins and susceptibility to each seems to vary from species to species. Although domestic and wild animals may be affected, this document will focus on the effects of mycotoxins on wild birds.

Exposure to mycotoxins has been responsible for die-offs of mallards, black ducks, lesser scaup, gadwall, blue and green-winged teal, Canada and snow geese, and sandhill cranes. Although mortality can occur anytime of year, the largest die-offs occur during fall and winter. This is because waterfowl and sandhill cranes consume large amounts of waste grain in fields during migration, and some types of mycotoxins tend to be produced primarily during the colder seasons of the year.

Although many different molds can produce mycotoxins, only two, Aspergillus and Fusarium, have been documented killing wild birds. The toxins produced by Aspergillus are most common on corn and peanuts. Symptoms usually observed include depression, lethargy (drowsy and sluggish), blindness, unawareness of surroundings, inability to

1. This document is WEC 190 and is one of a series of the Department of Wildlife Ecology and Conservation, Florida Cooperative Extension Service, Institute of Food and Agricultural Sciences (IFAS), University of Florida. First published: May 2005. Please visit the EDIS Web site at http://edis.ifas.ufl.edu for more publications.

2. Kristen L. Candelora is a Graduate Student and William M. Giuliano is an Assistant Professor and Wildlife Extension Specialist; Department of Wildlife Ecology and Conservation, Cooperative Extension Service, Institute of Food and Agricultural Sciences, University of Florida, Gainesville, FL 32611.

The Institute of Food and Agricultural Sciences (IFAS) is an Equal Opportunity Institution authorized to provide research, educational information and other services only to individuals and institutions that function with non-discrimination with respect to race, creed, color, religion, age, disability, sex, sexual orientation, marital status, national origin, political opinions or affiliations. U.S. Department of Agriculture, Cooperative Extension Service, University of Florida, IFAS, Florida A. \& M. University Cooperative Extension Program, and Boards of County Commissioners Cooperating. Larry Arrington, Dean 
fly, tremors, and wing flapping; often the birds are simply found dead.

The known die-offs associated with Aspergillus have mostly involved waterfowl. In 1977, there was a die-off in Harris County, Texas, that involved 500 birds, mainly geese. The birds died from mycotoxicosis after eating moldy corn and rice. As they were dying, their wings were outstretched and beat forcefully, until a slow relaxation occurred, the wings stopped beating, and the birds died quietly.

A second die-off, mostly mallards and pintails, occurred in Comanche and Eastland counties, Texas. From November through February of 1978, an estimated 7,000 birds were killed. In this event, most birds exhibited few symptoms other than general depression. These deaths were caused by mycotoxicosis from eating moldy peanuts.

The molds associated with Fusarium may grow on peanuts, corn, wheat, barley, and oats. These types of toxins tend to be produced during the colder seasons of the year. Toxin production usually occurs between 40 and 65 degrees Fahrenheit but can also occur at near freezing temperatures. Although the only documented cases of die-offs related to Fusarium have been in sandhill cranes, it is suspected that waterfowl could be affected as well.

When sandhill cranes eat food containing these molds it produces a distinctive syndrome, called Aneck Paresis Syndrome. This is because they experience a very obvious weakness of the neck (Figure 2). The birds' head and neck hang down as if they are looking at their feet; their wings may also droop as if they are unable to hold them up against their body. At first the birds may still be able to fly, as seen in Figure 3 of a sandhill crane getting ready to take flight. But, the birds cannot eat or drink because they are physically unable to lift their heads.

Between 1982 and 1987, approximately 9,075 sandhill cranes died in Texas and 470 sandhill cranes died in New Mexico. In both cases, the cause was mycotoxicosis from eating moldy peanuts left in the field after harvest. All mortality occurred between December and February. In addition, cold, wet weather favorable for toxin production occurred within the 15 days prior to the first signs of sickness.

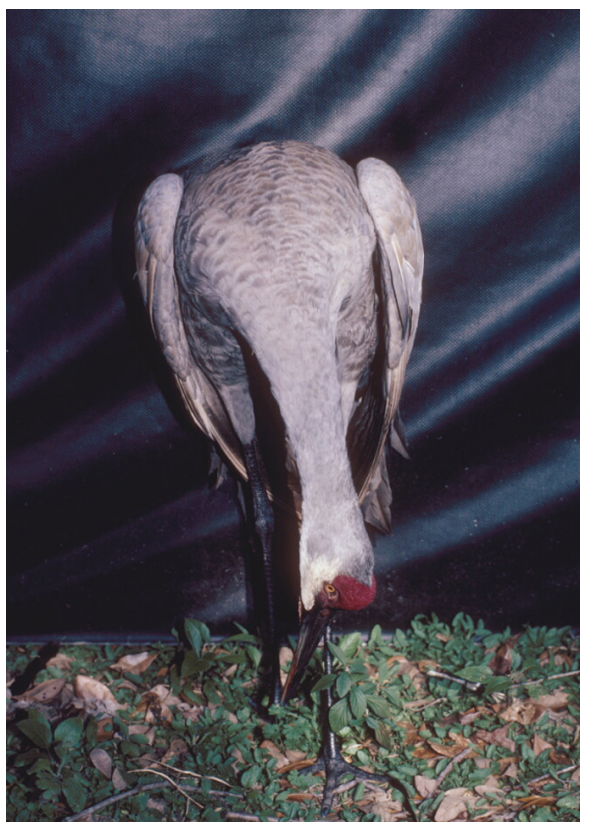

Figure 2. Sandhill cranes that eat foods containing the Fusarium fungus can develop Aneck Paresis Syndrome that causes weakness of the neck. Credits: Photo by FWC/S. Nesbitt.

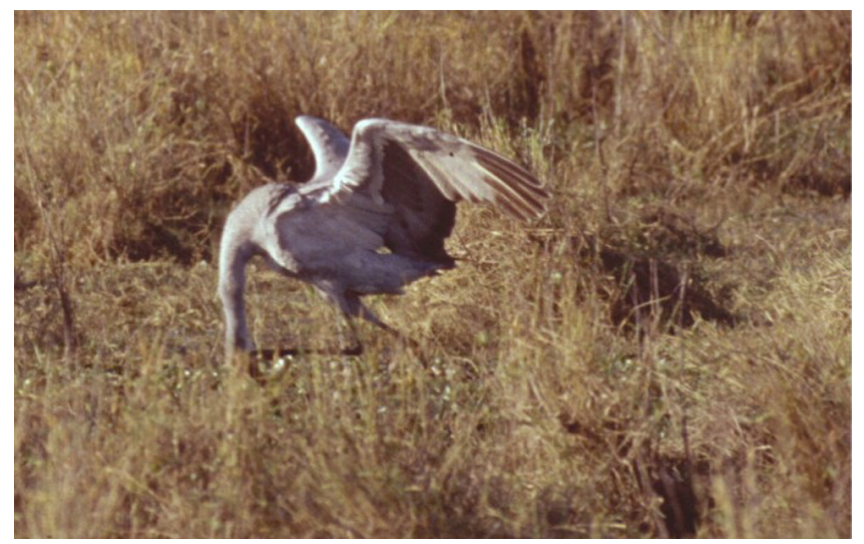

Figure 3. Although they may not be able to lift their head and neck, birds stricken with Aneck Paresis Syndrome may still try to fly. However, they have trouble eating and drinking. Credits: Photo by FWC/S. Nesbitt.

In 1986 and 1987, the Texas Parks and Wildlife Department contacted all peanut farmers in the area and asked for their help in controlling this problem. Most farmers voluntarily plowed under their peanut stubble immediately after harvest, and no sick or dead cranes were observed in the area in 1988.

Wildlife officials monitoring birds in areas near peanut farms first noted Aneck Paresis Syndrome in Florida in 1985. As in the other die-offs, the syndrome seems to be triggered by the onset of cold weather and lasts about three months. Up to 300 birds 
in Alachua, Levy, and Marion counties are affected by this syndrome each year. Numerous cranes with drooping necks have been admitted to the Florida Veterinary Medical Teaching Hospital, and some have been successfully rehabilitated and released. The most important part of rehabilitation seems to be elevating the head and isolating the birds from further consumption of toxins.

Making moldy peanuts unavailable to cranes and waterfowl by conventional tillage as soon as possible after harvest has resulted in reduced deaths in Florida and other areas where wild birds feed on peanuts. So if you see sick birds and suspect that your field may be tainted with either type of mold, the solution is simple: deep plow the field to bury peanuts/corn/grain in the soil where wild birds will be unable to feed on them (Figure 4). However, not all fields should be quickly plowed under, as waste and leftover crops are important foods for many wildlife species.

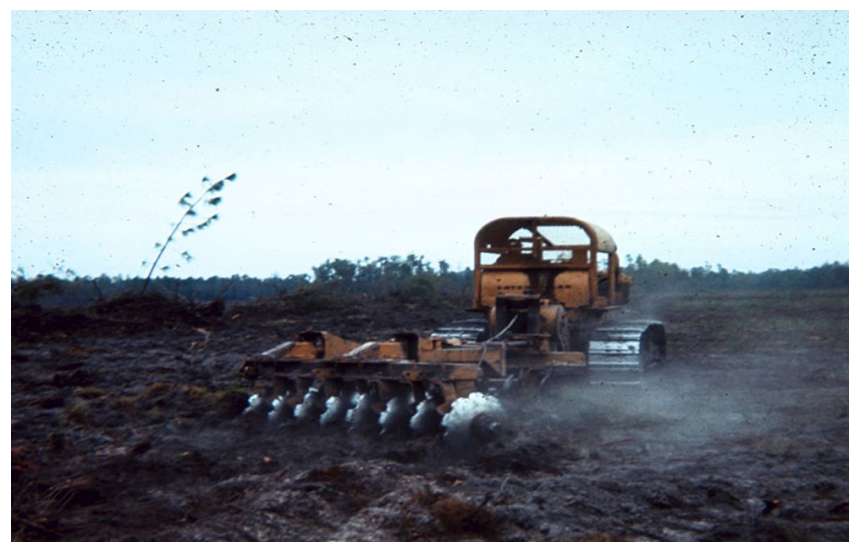

Figure 4. Plowing fields after harvest will bury leftover crops making them unavailable to birds, reducing the risk of poisoning. Credits: U.S. Department of Agriculture/Photo by J.D. Hodges.

\section{Want to Report Sick Birds?}

If you live in Florida and would like to report birds that may be suffering from mycotoxicosis, please call the Florida Fish and Wildlife Conservation Commission Wildlife Research Lab at (352) 955-2230.

\section{Information Available Online:}

For more information on the effects of mycotoxicosis on domestic animals see Alabama Cooperative Extension System Circular ANR-767.
You can find it on the Web at http://www.aces.edu/department/grain/ANR767.htm.

For more information on wild bird diseases in general see the USGS Field Manual of Wildlife Diseases: General Field Procedures and Diseases of Birds. You can find it on the Web at http://www.nwhc.usgs.gov/pub_metadata/ field_manual/field_manual.html.

\section{Bibliography}

Friend, M. and C. Franson. 1999. Field manual of wildlife diseases: general field procedures and diseases of birds. U.S. Geological Survey, Biological Research Division, Information and Technology Report 99-001.

Jacobsen, B.J., K.L. Bowen, R.A. Shelby, U.L. Diener, B.W. Kemppainen, and J. Floyd. Mycotoxins and mycotoxicoses, Alabama Cooperative Extension System, Circular ANR-767.

Norton, T.M., S. Nesbitt, R. Caligiuri, E.R. Jacobson, and G. Kollias. 2001. Therapy for mycotoxicosis in sandhill cranes (Grus canadensis) in Florida. Proceedings AAZV/AAWV/ARAV/NAZWV Joint Conference 82-84.

Robinson, R.M., A.C. Ray, J.C. Reagor, and L.A. Holland. 1982. Waterfowl mortality caused by aflatoxicosis in Texas. Journal of Wildlife Diseases 18:311-313.

Roffe, T.J., R.K. Stroud, and R.M. Windingstad. 1989. Suspected Fusariomycotoxicosis in sandhill cranes (Grus canadensis): clinical and pathological findings. Avian Disease 33:451-457.

Windingstad, R.M., R.J. Cole, P.E. Nelson, T.J. Roffe, R.R. George, and J.W. Dorner. 1989. Fusarium mycotoxins from peanuts suspected as a cause of sandhill crane mortality. Journal of Wildlife Diseases 25:38-46.

Windingstad, R.M., R.R. George, and R.F. Krey. 1985. Sandhill crane mortality at Cedar Lake, Texas-an overview. Pages 137-139 in J.C. Lewis, editor. Proceedings of North American crane workshop. 